\title{
Assessment of Private Sector Financing of Electricity Infrastructure in Nigeria
}

\author{
${ }^{1}$ Ahmed, A., ${ }^{2}$ Landi, J. H. \\ ${ }^{1}$ Accounting and Finance Technology Programme, ATBU, Bauchi. \\ ${ }^{2}$ Department of Economics, University of Jos.
}

\begin{abstract}
There is a huge deficit in the infrastructure sector of the Nigerian economy. The country generates less than 4000 Mega Watts of electricity for a population of about 160 million people. Because of the low generation of electricity in Nigeria, load shedding is the order of the day. Consumers are forced to do without grid supplied electricity for the most part of the day. All governments' efforts to reverse the dismal performance of the industry failed to produce the desired effects. In 2005, government introduced market reform through the Electric Power Sector Reform Act (EPSR) to reform and restructure the industry to allow for private sector participation in the financing of electricity generation infrastructure as a way of boosting electricity supply to the national economy. However private investment flow to NESI has been slow. The research sought to find out the reasons for the slow pace of private sector investment flow to the industry. Structured questionnaires using Likert scale were distributed to top management of privately licensed firms to generate data for analysis. Multiple regressions were used for data analysis. The analysis reveals a significant influence of the independent variables on the $D V$ with $p=0.000<0.005$. This therefore shows that government policy of meeting the generation needs of the electricity industry could be met through the participation of the private sector. However a lot needs to be done to fast track the flow of private investment to the industry.
\end{abstract}

Key words: Electricity Generation, Private Investment, Infrastructure, Power Project Finance and Government Incentives.

\section{Background}

Infrastructure facilities are crucial to the operations of the contemporary economy. For example transport infrastructure facilitates the movement of raw materials and people necessary for the organization of production and finished goods to end users. Infrastructure availability and its quality determine the success or otherwise of an economy (Merna \& Njiru, 2002; Todaro \& Smith, 2006). With a population of about 160 million people and an electricity generation level of less than 4000 megawatts, there is a pronounced electricity supply deficit in Nigeria and closing the gap is going to be a daunting task. That is why in almost every forum and in every household the usual topic of discussion has been the failure of the Power Holding Company (PHCN) to provide stable electricity supply for residential, commercial and industrial consumptions. Because the success of the contemporary economy depends on the continuous supply of electricity, it becomes necessary for massive and sustained investment to be made in order to develop the infrastructure base of the Nigerian Electric Supply Industry (NESI).This will enhance the contribution of NESI to the national economy (Adenikinju, 2005; Iwayemi, 2008b).

To deal with the growing supply deficit, the Nigerian government promulgated the Electric Power Sector Reform (EPSR) Act (2005) which recognizes the participation of the private sector as the key strategy to energy infrastructure development in Nigeria. The Act seeks to infuse competition into NESI and change the monopolistic structure of the market .This is ultimately expected to enhance electricity supply which will promote economic development of the nation. Many private sector firms have been licensed to generate electricity in Nigeria. A few of them have already built generating infrastructure and have started contributing to the national grid. Some of them are at various stages of building the infrastructure. However other licensed private generators are yet to start the development of the generation infrastructure after they have been granted license for many years. This research work has been designed to find out why private investors are reluctant to invest in the Nigerian electricity supply industry.

\subsection{Problem Statement}

Nigeria's desire to attain an economic super power status by the year 2020 will greatly depend on her ability to enhance her power generation, transmission and distribution infrastructures among others (FGN, 2010). Today consumers of electricity (domestic, commercial and industrial) have to generate substantial portion of their requirements due to low supply of electricity by PHCN (Adenikinju, 2005). It is estimated that up to $20 \%$ of investment cost of industrial projects in Nigeria is used to provide alternative source of electricity (Adenikinju, 2005; Iwayemi, 2008a). The impact of this on the business sector has been the increasing costs of 
production and loss of business competitiveness among Nigerian firms (at both domestic and international markets). The dismal performance of the energy sector has also adversely affected the living standard of the people and has exacerbated income and energy poverty among Nigerians (Iwayemi, 2008b).

The electricity industry dominated by the PHCN (which is entirely owned by the government) has been characterised by poor service delivery in the forms of recurrent 'black-outs' and 'brown -outs, high energy losses (both technical and non-technical) due to poor transmission and distribution infrastructure and low capacity utilization (around $40 \%$ of installed capacity). There is also lack of investment in the industry's infrastructures despite the fact that most of the infrastructure in the industry have remained old and subserviced (Adenikinju, 2005; Iwayemi, 2008b; Federal Ministry for Energy, 2008, Obadote 2009,). Ilori, (2002) links the poor performance of the sector to the public ownership of PHCN, inadequate and inefficient delivery of services relative to the demand for such services, excessive regulation, obsolescence /poor equipment maintenance and investment, political interference among others. To address the problems in the sector the government introduced electric power sector reform captured in the EPSR Act (2005). The reform seeks to re-structure the industry and allow private sector participation in those parts of the industry which are open to competition (NERC, 2008). The private sector operators which largely exist as Independent Power Projects (IPPs) operate at the generation segment of the industry where it is possible to introduce competition. The IPPs produce power and sale to the national grid through a contract known as power purchase agreement (PPA). As at November 2011, NERC has licensed more than 50 firms who have signified their intention to invest in the generation of electricity in Nigeria. However, despite the incentives and other promotional efforts of the government only few licensed firms have completed Engineering, Procurement and Construction(EPC) and are producing electric power for both grid and non- grid consumptions.

\subsection{Objectives of the Research Work}

The objective of the study is to assess the role of power project finance in stimulating the flow of private investment for the development of electricity generation infrastructure in the Nigerian electricity supply industry.

\subsection{Hypothesis}

The work has been structured on the following hypotheses:

Hypothesis 1

Ho: Power project finance does not have significant impact on the flow of private investment to the Nigerian electricity supply industry.

\section{Review of Related Literature}

The term infrastructure has its origin in the military where it was used to describe the buildings, installations and communication networks necessary for sending supplies and messages (Scheneider and Jager 2003). The term was borrowed from the Romans languages where it was used to describe immovable parts of the transportation system such as the structure of railways and air ports. According to Hirschman (1958: 83) infrastructure refers to "those services without which primary, secondary and tertiary production activities cannot function. In its widest sense, it includes all public services from law and order through education and public health to transportation, communication, power and water supply as well as such agricultural overhead capital as irrigation and drainage systems" (Hirschman, 1958:83). Hirschman's definition of infrastructure is broad. They however demonstrate the necessity of infrastructure to the wellbeing of the economy and society. Oyeranti (2001:1) sees 'infrastructure as the basic inputs required for the functioning of an economy'. Cameron (2006) sees infrastructure as the skeleton of the economy which supports the flesh and muscle of the economy. Cameron's definition also emphasises the input nature of infrastructure and its necessity to the process of production in particular and the general operation of the entire economy.

OECD (2007:13) sees infrastructure as the "means for ensuring the delivery of goods and services that promotes prosperity and growth and contribute to quality of life including the social well-being, health and safety of citizens, and the quality of their environments"

\subsection{Functions of Infrastructure}

Infrastructure plays vital roles in the functioning of the economy through multifarious channels. Infrastructure impacts on investment and firm level performance (Reinikka and Svensson, (1999, 2002), impacts on output and welfare of the people (Arrow and Kurz, (1970). Infrastructure has been shown to have direct effect on total factor productivity (Aschuer, 1989). Studies by Estache, Foster and Wodon, (2002), Estache ,(2003), Calderón and Servén, (2008) show the link between infrastructure and income distribution. Infrastructure availability therefore reduces income inequality by expanding access by the poor to infrastructure services. There is also a growing evidence of infrastructure's effects on poverty reduction, where investment in 
infrastructure especially road infrastructure has been shown to improve local community and market development (Escobal and Ponce, 2002; Lockshin and Yemtsov, 2005; Khandker, et al , 2006, Mu and van de Walle, 2007). Estache, Specialle and Veredas, (2005) discusses the developmental of infrastructure. The importance of infrastructure to the proper functioning of the economy is aptly captured by President Goodluck Ebele Jonathan at the CBN Infrastructure Finance Conference in December ,2010 where he observed that that huge infrastructural deficits have, over the years, constrained the production of goods and services, functioning of industries, movement of goods and persons, trade and commerce, marketing, banking, health, education and adversely affected other aspects of lives'.

\subsection{Private Investment in Electricity Infrastructure}

The history of private sector participation in the financing of electricity infrastructure dates back to the early spread of electricity in the 1800 s. They were however considered strategic industries and taken over by the government. However governments have gradually begun to withdraw from the business of infrastructure service provision including electricity generation and are being replaced by the private sector. The key drivers of private sector participation in the electricity sector include government's fiscal difficulties and their(governments') failure to meet investment and operational resource needs of their SOEs, poor performance of SOEs, policy changes in the multi lateral lending institutions, massive liquidity and tight domestic returns in Europe and America (Zhang, Parker and Kirkpatrick 2002), technological advancement in the infrastructure sector and the ideological explanations (Dailami and Klien, 1997: Estache, 2005:, Woodhouse, 2005, 2006). Private infrastructure projects are developed through project finance (UNCITRAL, 2001) which is an arrangement where projects are developed through a special entity different from its promoters often referred to as the project company or special purpose vehicle(SPV) which provides the avenue for raising funds for financing the projects. Lenders look to the project's cash flow as the basis of the security of their lending. The projects are referred to as either as non-recourse or limited recourse projects (Babber and Schuster, 1998; Dailami, Lipkovich and Van Dyck, 1999).Private power projects are usually developed through power project finance an arrangement where the promoters of the projects put the project entity and raise the funds needed for the project largely through long term debt. Most of the investments are made by Independent Power Producers(IPPs) and are structured through a long term contractual relationship known as Power Purchase Agreement which describes the off take arrangement between the power producers and the off taker(usually an SOE).

Sources of raising funds for power project finance include equity capital (ranging between 20 to $40 \%$ ), short term commercial loans, subordinated debt /mezzanine capital, institutional investors, the capital market and Islamic Financial Institutions.

\subsection{The Nigerian Electricity Supply Industry}

The historical background of electricity supply in Nigeria dates back to 1896 with the installation of the first electricity generating plant in Lagos by the then Colonial administration (Okoro and Chikunu, 2007). This was managed by the Public Works Department. The first Electricity Corporation Ordinance (ECO) was enacted in 1950 which created the Electricity Corporation of Nigeria (ECN). This was followed by the 1962 Niger Dam Authority (NDA) Act which created regional electricity bodies that later metamorphosed into NEPA through Decree 4 of 1972.

Nigeria's electricity supply is very low even on Africa's standard. For example Egypt with a population of 77 million generates about 23,000 MW. South Africa with a population of about 49 million generates about 36,000 MW. Because of the low generation of electricity of the sector Nigeria's electricity, consumption per head measured as kilowatts hour per capita is among the lowest in the world (Lawal 2008, Okafor 2009).

Table 1 Comparative Analysis of Electricity Consumption World Wide

\begin{tabular}{lrrc}
\hline Country & Population & Power Generation & Per Capita Constumption \\
\hline United States & 250.00 Million & $813,000 \mathrm{MW}$ & $3.20 \mathrm{KW}$ \\
Cuba & 10.54 Million & $4,000 \mathrm{MW}$ & $0.38 \mathrm{KW}$ \\
United Kingdom & 57.50 Million & $76,000 \mathrm{MW}$ & $1.33 \mathrm{KW}$ \\
Ukraine & 49.00 Million & $54,000 \mathrm{MW}$ & $1.33 \mathrm{KW}$ \\
Iraq & 23.60 Million & $10,000 \mathrm{MW}$ & $0.42 \mathrm{KW}$ \\
South Korea & 47.00 Million & $52,000 \mathrm{MW}$ & $1.09 \mathrm{KW}$ \\
South Africa & 44.30 Million & $45,000 \mathrm{MW}$ & $1.015 \mathrm{KW}$ \\
Libya & 5.50 Million & $4,600 \mathrm{MW}$ & $1.015 \mathrm{KW}$ \\
Egypt & 67.90 Million & $18,000 \mathrm{MW}$ & $0.265 \mathrm{KW}$ \\
Nigeria & 140.00 Million & $4,000 \mathrm{MW}$ & $0.03 \mathrm{KW}$ \\
\hline
\end{tabular}

Source:Agbo ,(2007) as cited by Okafor, (2008:2)

As can be seen Nigeria's per capita consumption is $0.03 \mathrm{KW}$ hour. This does not compare with $0.265 \mathrm{KW}$ for Egypt, 1.015 for South Africa and Libya respectively. Because of the poor electricity supply to the Nigerian economy, private provision by consumers has become the norm (Adenikinju, 2005). For example firms allocate 
substantial proportion of their capital to provide backup generating facility due to poor and unreliable electricity supply from the grid (Ajayi, 1995:, Iwayemi ,2008).

\subsection{Power Sector Reform in Nigeria}

As a way of reversing the dismal performance of the sector, government introduced the power sector reform through the promulgation of Electric Power Sector Reform Act (2005) to open the market for private sector investment for the generation and sale of electricity. The reform of the sector led to the unbundling of NEPA (into 6 generation companies, 11 distribution companies and 1 transmission companies), creation of the industry regulator (NERC), establishment of the bulk purchaser (NBETC) and the legacy company (NELCOM). To attract the private sector to the industry, government introduced certain incentives which include stable securitization, power purchase agreement (PPA), tariff review (MultiYear Tariff Order) provision of data on electricity demand of the country, provision of data on energy resources of country, electricity transmission infrastructure upgrade and complementary reform in the gas industry. Other incentives include 3-5 years tax holidays, tax exemption on dividend paid during pioneer status, exemption from duty taxes on imported equipments, capital and investment allowances.

\subsection{Research Methodology}

The research adopts a cross sectional survey research design to undertake the study in line with the work of Adenikinju, (2005); Jamasb ,(2005); Kerekezi ,(2002); Lee and Anas, (1998) ; Renieka and Svenson, (1999, 2002); Wallsten, Clarke , Haggarty, Kaneshiro, Noll, Shirley and Xu , (2004) ; Woodhouse ,(2005), (2006) among others

The research draws sample from the population of managers of the licensed private firms (often referred to as IPPs). Data was gathered from the selected sample through the use of structured questionnaire.

The sample size of the study was determined using Yamane (1967) formula for normal approximation at $95 \%$ confidence level and 5\% error margin. Thus the sample size was arrived at using the below formula:

$\mathrm{n}=\mathrm{N} / 1+\mathrm{Ne}^{2}$

Where;

$\mathrm{N}=$ the population size $(540)$

$\mathrm{n} .=$ the sample size $(230)$

e. $=$ level of precision $(0.05)$

$1=$ constant

Sample Size $n=N / 1+N(e)^{2}=540 / 1+540(0.05)^{2}=540 / 2.35=230$ respondents. Therefore the sample size for the research is 230 out of the population of 540 managers.

The above sample size meets the sample size requirements for multivariate analysis as recommended by Green, (1991): Hair, Anderson, Tatham, \& Black, (1995): Oppenheim, (1996): Tabachnick and Fidell, (2007) and Pallant, (2011).

Sample for the study was selected through the use of simple stratified random sampling from the population of managers in the licensed private companies in Nigeria. The stratified sampling procedure allows the researcher to draw a sample in such a way that the researcher is assured that certain sub-groups in the population will be represented in proportion to their numbers (Borg and Gall, 1978).

Data was collected through the use of structured questionnaire which were administered to the sampled respondents. The questionnaire was designed using the Likert Scale format. The questionnaire consists of 6 sections capturing the 6 constructs of the study which are Power project finance (FP), Industry Operational Environment (OPE), Government's Incentive Package (GIP), Industry Tariff Structure (ITS), Policy Option (PO) and the Flow of Private Investment (FPI). The sample size of the research is 230 respondents. However a $30 \%$ non response rate was assumed due to the declining rate of survey research response (de Leeuw and de Heer, 2002) especially where top level managers of private organizations are the respondents and the need to ensure the generation of the adequate data needed for the conduct of the analysis in line with the recommendations of Hair, et al, (2006); Hinton, (2010); Tabbachnic and Fidel, (1996); Pallant, (2011) among others

Scale validation and reliability tests were conducted to establish the validity and reliability of the measuring instruments. The research instrument was exposed to content and face validity. The content of the instrument were developed through extensive literature search. Additionally the instrument was sent to some scholars, industry practitioners and regulators who made important input into the instrument. The instrument was also exposed to construct validity to establish convergent validity (which is explored by investigating the relationship between the construct with other constructs) and discriminant validity (which is measured by establishing the extent to which the construct diverges or differs from other construct of the study) using the Pearson Correlation Matrix. 
Table 1: Correlation Matrix :Dependent Variable :FPI

\begin{tabular}{|c|c|c|c|c|c|c|c|}
\hline & & PF & OPE & GIP & ms & po & FPI \\
\hline \multirow[t]{3}{*}{ PF } & Pearson Correlation & 1 & .128 & $.857^{-1}$ & $249^{-}$ & .086 & $.575^{-}$ \\
\hline & Sig. (2-tailed) & & .104 & .000 & .001 & .277 & .000 \\
\hline & $\mathrm{N}$ & 162 & 162 & 162 & 162 & 162 & 162 \\
\hline \multirow[t]{3}{*}{ OPE } & Pearson Correlation & .128 & 1 & $225^{\circ}$ & $.180^{\circ}$ & -.109 & .031 \\
\hline & Sig. (2-tailed) & .104 & & .004 & .022 & .188 & .698 \\
\hline & $\mathrm{N}$ & 162 & 162 & 162 & 162 & 162 & 162 \\
\hline \multirow[t]{3}{*}{ GIP } & Pearson Correlation & $657^{-1}$ & $225^{-1}$ & 1 & $.380^{-}$ & -.059 & $.503^{-}$ \\
\hline & Sig. (2-tailed) & .000 & .004 & & .000 & .453 & .000 \\
\hline & $\mathrm{N}$ & 162 & 162 & 162 & 162 & 162 & 162 \\
\hline \multirow[t]{3}{*}{ ITS } & Pearson Correlation & $249^{--}$ & $.180^{\circ}$ & $380^{-*}$ & 1 & $-197^{\circ}$ & $.161^{\circ}$ \\
\hline & Sig. (2-tailed) & .001 & .022 & .000 & & .012 & .040 \\
\hline & $\mathrm{N}$ & 162 & 162 & 162 & 162 & 162 & 162 \\
\hline \multirow[t]{3}{*}{ PO } & Pearson Correlation & .086 & -109 & -.059 & $-.197^{\circ}$ & 1 & $.169^{\circ}$ \\
\hline & Sig. (2-tailed) & 277 & .168 & .453 & .012 & & .032 \\
\hline & $\mathrm{N}$ & 162 & 162 & 162 & 162 & 162 & 162 \\
\hline \multirow[t]{3}{*}{ FPI } & Pearson Correlation & $575^{-}$ & .031 & $.503^{--}$ & $.181^{\circ}$ & $.189^{\circ}$ & 1 \\
\hline & Sig. (2-tailed) & .000 & 698 & .000 & .040 & .032 & \\
\hline & $\mathrm{N}$ & 162 & 162 & 162 & 162 & 162 & 162 \\
\hline
\end{tabular}

In addition to the validity test conducted, the instrument was also exposed to reliability test to determine their reliability i. e. the extent to which repeated application of the instrument will produce similar result. The Cronbatch alpha was used to estimate the degree of reliability of the measuring instrument.

Table 1 shows the result of the construct reliability test conducted Table 1: Construct Reliability.

\begin{tabular}{lccc}
\hline Constructs & Questionnaire Item & Cronbach Alpha & Reliability Status \\
\hline PF & 8 & .77 & High Reliability \\
OPE & 5 & .58 & Moderate Reliability \\
& & & High Reliability \\
GIP & 12 & .88 & Moderate Reliability \\
ITS & 7 & .67 & Moderate Reliability \\
PO & 8 & .66 & High Reliability \\
FPI & $\mathbf{9}$ & .87 &
\end{tabular}

Source: Field Survey Data, 2012

Three constructs have high reliability with PF construct having 77\% reliability, GIP construct having $88 \%$ reliability and FPI construct having $87 \%$ reliability. The remaining constructs have moderate reliability. Construct OPE has $58 \%$ reliability, constructs PO has $66 \%$ reliability while construct ITS has $67 \%$ reliability.

\subsection{Data Analysis}

Descriptive statistics such as frequency distribution, measures of central tendencies (means, mode and median) and measures of dispersion (range, variance, standard deviation ,inter quatile ) were used in data cleaning and data preparations preparatory to inferential data analysis as recommended by Coakes, (2005), Hair, (2006) , Pallant (2011) and Tabachnick and Fiddel, (2007). Other descriptive statistics used include skewness and kurtosis (for establishing data normality) QQ Plots, NPP Plots, histograms, box plots and Kolmogrov- Sminov (for inspecting compliance with all the multiple regression assumptions).

Standard multiple regression analysis was used to conduct the data analysis and test the hypotheses of the research. Multiple regressions is a dependency technique used to describe the extent of linear relationship between a dependent variable and a number of other independent variables (Frankfort-Nachmias \& Nachmias, 1996; Cooper and Schindler, 2011; Hair, etal, 2006). Standard multiple regressions is used to evaluate the relationships between a set of independent variables (IVs) and a dependent variable (DV). In standard multiple regressions all the IVs are entered into the regression equations at the same time and the multiple $\mathrm{R}$ and $\mathrm{R}^{2}$ are used to measure the strength of the relationship between the IVs and the DV. An $\boldsymbol{F}$ test is used to determine if the relationship can be generalized to the population as represented by the sample while a $t$ test is used to determine the relationship between each individual IV and the DV. A multiple regressions model is expressed as;

$\grave{Y}=\beta_{0}+\beta_{1} x^{1}+\beta_{2} x^{2}+\beta_{3} x^{3}+\beta_{4} x^{4}+\beta_{5} x^{5}+e$

Where 
ßo - is a constant, the value of $\grave{Y}$ when all values of $X$ are zero

Bi- the slope of the regression surface (the regression coefficient associated with each X).

e- an error .

The use of multiple regression models requires compliance with certain assumptions. These assumptions include sample size requirements, absence of multicollinearity and singularity, detection of outliers, and the assumption of normality, linearity, homoscedascity and independence of residuals. The sample size of the research at 161 (used for the final analysis after deletion of univariate, bivariate and multivariate outliers) has reached the sample size requirements as recommended by Steven, (1996); Hair et al, (2006); Tabachnik and Fiddle (2007); Pallant, $(2001,2011)$. Normality of the data distribution is assessed through physical and numerical means. The physical examination is done through the examination of graphs such as box plot, histogram, PP plot, QQ plot. On the other hand the numerical assessment is done through kurtosis and skewness. Box plot was used to detect and delete many univariate outliers. Additionally collinearity diagnosis was used to detect bivariate and multi variate outliers. An examination of the histograms of the two models indicates a fairly normally distributed data which implies the absence of substantial outliers. Additionally the normality of the variables distributions was examined through inspecting the residuals scatter plot and the Normal Probability plot of the regression standardised residuals as advocated by Osborn and Waters (2002), Pallant, (2011) and Tabachnick (2007). The Normal Probability Plot in figures 2 and 3 indicates that points reasonably lie on the straight diagonal lines indicating the absence of outliers in the model. Additionally an examination of the correlation matrix indicates the absence of multicolinearity among the independent variables as non of the constructs has an $\mathrm{r}$ up to or greater than .9 which indicates the presence of multicollinearity as suggested by Ahmad, (2009); Hair et al., (2006); Pallant, (2001), Pallant, (2011) and Tabachnick , (1996, 2007). An examination of the collinearity diagnostic statistics in table 69 indicates the absence of multicollinearity as the tolerance level for all the constructs are above the threshold of .10 which according to Hair et al, (2006), Pallant, (2011) indicates the presence multi collinearity in the IVs.

\section{Normal P.P Plot of Regression Standardized Residual}

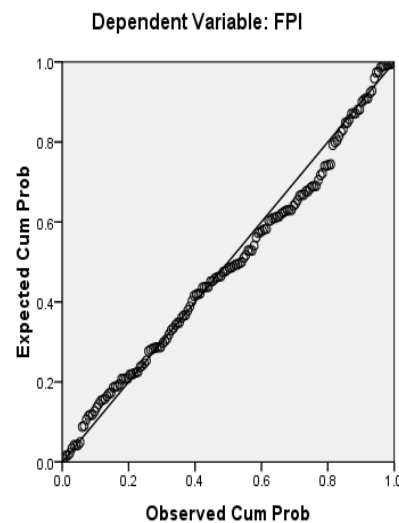

Figure 1: Normal PP Plot: Dependent Variable FPI.

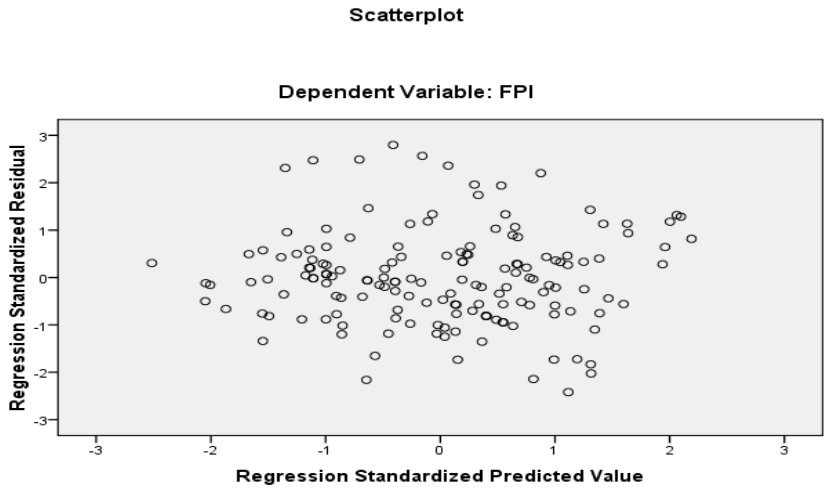

Figure 2: Scatter plot. 


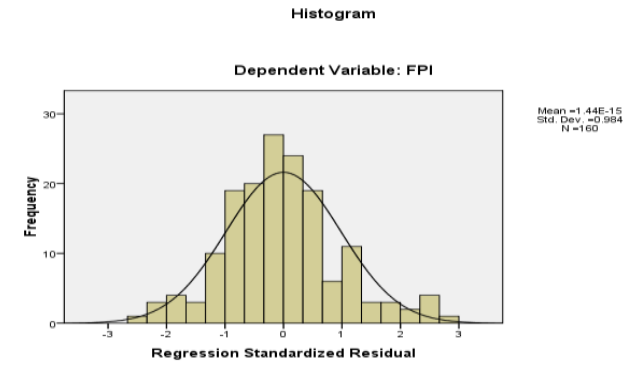

Figure 3: Histogram.
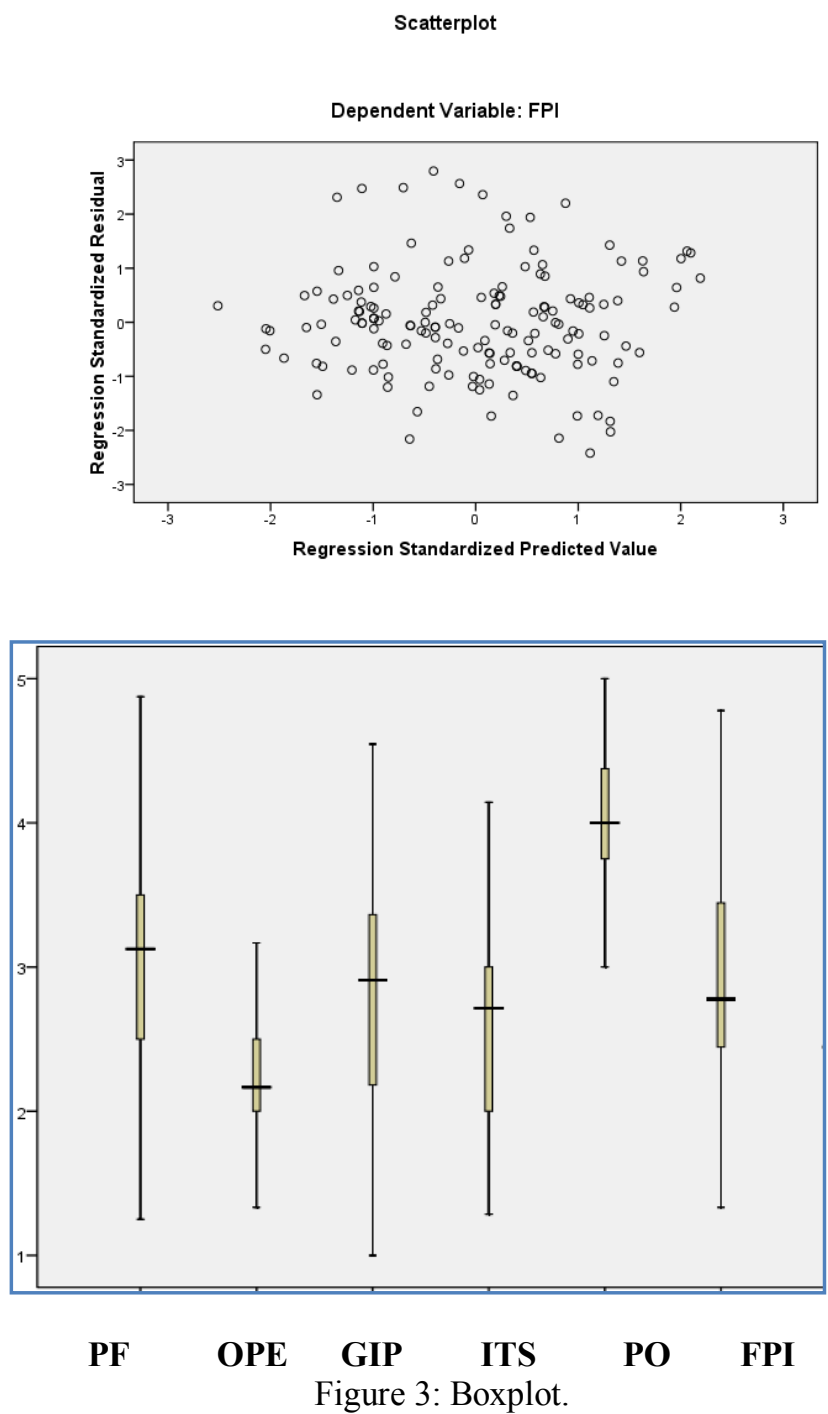

Data screening and cleaning were conducted to ensure that data was accurately entered into the data file, to detect missing data, and to ensure that outliers are detected and acted upon recommended by FrankfortNachmias and Nachmias, Hair et al, (2006); (2009); Pallant, (2001) The frequency table in appendix 4 provides a glimpse of relevant statistics that allow for error detections and missing data detection through the examination of out of range, scores (through the maximum and minimum scores) the mean, the median and the mode scores as well as the standard deviation scores and skewness and kurtosis as recommended by Coakes (2005), Palllant, (2011) and Hair et al, (2006). All out of range scores were corrected and consequently all scores for the variables were within 1-5 range. Missing data were detected and appropriate actions taken on them. 299 questionnaires to the respondents out of which 215 were returned representing about $72 \%$ of the total questionnaires distributed. Out of these about 3 questionnaires were returned unfilled. Closer examination revealed 5 morbidity cases where the respondents tick in one option throughout the questionnaire that is ticking 
strongly agreed, agreed, undecided, disagreed or strongly disagreed throughout the questionnaire. A total of 207 questionnaires remained and were entered into the data file. Each questionnaire was given an ID number for easy identification and correction where necessary. Negatively worded questions (items) in the questionnaire were reversed before the commencement of the analysis as recommended by Cooper and Schindler, (2011), Hair et al (2006), Pallant, (2011), , and Tabbachnik and Fiddel, (2007)

\section{Model Test}

Table 67 : Model Summary
\begin{tabular}{|l|l|l|l|l|}
\hline Model & $R$ & R Square & $\begin{array}{l}\text { Adjusted } \\
\text { Square }\end{array}$ & $\begin{array}{l}\text { R } \\
\text { Std Error of } \\
\text { the Estimate }\end{array}$ \\
\hline 1 & $.678^{2}$ & .460 & .443 & .58052 \\
\hline
\end{tabular}
a. Predictors: (Constant), PO, GP, OPE, ITS, PF
b. Dependent Variable: FPI

Table 67 depicts the model summary and shows the $\mathrm{r}$ and $\mathrm{R}^{2}$ values of the model. The model shows that the IVs account together for $46 \%$ of variations in the dependent variable (FPI).

\begin{tabular}{|c|c|c|c|c|c|c|}
\hline \multicolumn{2}{|c|}{ Model } & \multirow{2}{*}{\begin{tabular}{|l}
$\begin{array}{l}\text { Sum } \\
\text { Squares }\end{array}$ \\
44.227
\end{tabular}} & \multirow{2}{*}{$\frac{\text { Df }}{5}$} & \multirow{2}{*}{\begin{tabular}{|l} 
Mean Square \\
8.845
\end{tabular}} & \multirow{2}{*}{\begin{tabular}{|l}
$F$ \\
26.247
\end{tabular}} & \multirow{2}{*}{$\frac{\text { Sig. }}{.000^{2}}$} \\
\hline 1 & Regression & & & & & \\
\hline & Residual & 51.898 & 154 & .337 & & \\
\hline & Total & 96.125 & 159 & & & \\
\hline
\end{tabular}

The ANOVA Table shows that the independent variables' influence on the dependent variable is significant with $p=.000$. Thus the $p$ value is significant $(\mathrm{p}<0.05)$.

Evaluating Individual Variable's Contribution to the Model.

Here we look at the individual variable's contribution to the model by looking at the standardized coefficients beta values against each variable.

Table 69: BetaCoefficients ${ }^{a}$ and Collinearity Statistics

\begin{tabular}{|c|c|c|c|c|c|c|c|c|}
\hline \multirow{2}{*}{\multicolumn{2}{|c|}{ Model }} & \multicolumn{2}{|c|}{ Unstandardized Coefficients } & \multirow{2}{*}{$\begin{array}{l}\text { Standardized } \\
\text { Coefficients } \\
\text { Beta }\end{array}$} & \multirow[b]{2}{*}{$\mathrm{t}$} & \multirow[b]{2}{*}{ Sig. } & \multicolumn{2}{|c|}{ Collinearity Statistics } \\
\hline & & B & Std. Error & & & & Tolerance & VIF \\
\hline \multirow[t]{6}{*}{1} & (Constant) & -.063 & .558 & & -.112 & .911 & & \\
\hline & $\mathrm{PF}$ & .505 & .089 & .447 & 5.666 & .000 & .564 & 1.774 \\
\hline & OPE & -.148 & .113 & -.080 & -1.310 & .192 & .930 & 1.075 \\
\hline & GIP & .315 & .092 & .282 & 3.430 & .001 & .517 & 1.934 \\
\hline & ITS & .022 & .079 & .018 & .280 & .780 & .828 & 1.208 \\
\hline & $\mathrm{PO}$ & .209 & .106 & .121 & 1.969 & .051 & .926 & 1.079 \\
\hline
\end{tabular}

a. Dependent Variable: FPI

The beta table displays the contributions of each variable to the model.The construct PF (power project finance) makes the greatest unique contribution to the model by explaining about $45 \%$ of the variance in the dependent variable with a $\mathrm{p}$ value of .000 which is less than the significance level or $0.05(\mathrm{p}<0.05)$. Construct GIP (government incentive package) also makes a unique contribution by explaining about $28 \%$ of the variance in the dependent variable with a significance level of $.001(\mathrm{p}<0.05)$. Construct PO (policy option) contributes about $12 \%$ to the explanations of the variations in the dependent variable with a $\mathrm{p}$ value of .051which is not significant ( $p>0.05$ ). Construct OPE (industry operational environment) contributes -8 to the model with a $p$ value of .192. Since $p>0.05$ the construct influence is not significant. On the other hand the model ITS (industry tariff structure) contributes about $2 \%$ to the model's explanations on the dependent variable with a $p$ value of $.780(\mathrm{P}>0.05)$ and thus it has an insignificant influence on the model. 
Test of Hypotheses.

The hypothesis to be tested is

Ho: Power project finance does not have significant impact on the flow of private investment to the Nigerian electricity supply industry.

H1: Power project finance has significant impacts on the flow of private investment to the Nigerian electricity supply industry.

Table 2 presents the model summary which presents the $r$ and $R^{2}$ values which are .678 and .460 respectively. This indicates that the model has a $46 \%$ explanatory power over the dependent variable. In other words the model explains about $46 \%$ variation in the dependent variable. Table 3 is the ANOVA table which shows the level of significance of the model on the dependent variable. The table shows a $p$ value of .000 . Thus the model has a significant effect on the dependent variable. Thus $\mathrm{p}<0.05$.

\section{Decision rule:}

Reject Ho if $\mathrm{P}<0.05$

Accept Ho if $\mathrm{P}>0.05$

Going by the decision rule therefore the null hypothesis which states that power project finance does not have significant impact on the flow of private investment to the Nigerian electricity supply industry is rejected and the alternate hypothesis which states that power project finance have significant impact on the flow of private investment to the Nigerian electricity supply industry is accepted.

The standard multiple regressions model therefore is represented as

$\mathrm{Y}=\mathrm{bo}+\mathrm{B}_{1} \mathrm{X}_{1}+\mathrm{B}_{2} \mathrm{X}_{2}+\mathrm{B}_{3} \mathrm{X}_{3} \ldots+\mathrm{B}_{\mathrm{n}} \mathrm{X}_{\mathrm{n}}+\mathrm{e}$

Where $\mathrm{Y}$ is the dependent variable FPI, $\boldsymbol{b o}$ is the intercept, $\mathrm{X}_{1}, \mathrm{X}_{2}, \mathrm{X}_{3}$ are the coefficients of the independent variables of the study.

Therefore

$\mathrm{FPI}=\mathrm{bo}+\mathrm{b}_{1} \mathrm{PF}+\mathrm{b}_{2} \mathrm{OPE}+\mathrm{b}_{3} \mathrm{GIP}+\mathrm{b}_{4} \mathrm{ITS}+\mathrm{b}_{5} \mathrm{PO}-\ldots+\mathrm{e}$

Where $\boldsymbol{b o}$ is the intercept i.e. the value of $\boldsymbol{Y}$ when the values of the IVs are all equal to zero, $\boldsymbol{P F}$ is the power project finance variable, $\boldsymbol{O P E}$ is the industry operational environment, $\boldsymbol{G I P}$ government incentive package, $\boldsymbol{I T S}$ is the industry tariff structure and $\boldsymbol{P O}$ is the policy options while $\boldsymbol{e}$ is the error term.

$\mathrm{Y}(\mathrm{FPI})=-0.63+.505+.148+.315+.022+.209-\ldots$

$\mathrm{Y}=-0.63+.505 \mathrm{PF}+.148 \mathrm{OPE}+.315 \mathrm{GIP}+.022 \mathrm{ITS}+.209 \mathrm{PO}$

\section{Discussion}

Nigeria's electricity sector has failed to meet the electricity needs of the nation( Adenikinju,2005; Ebherhard, 2012; Iwayemi, 2008b) due largely to the public ownership structure of the industry (Ilori, 2002) and government inability to expand investment in the sector to meet the growing demand for electricity services(Iwayemi, 2008a). Consequently government introduced the reform of the industry to pave way for private sector investment in the generation segment of the industry and to introduce competition to enhance power generation and supply. However despite the grant of licenses by the government to many private sector firms very few firms have invested in the development of electricity generation infrastructure. The study sought to find out the reasons for the low private sector investment in the NESI despite the granting of licenses to many private firms.

The independent variable PF indicates the immense potentials that power project finance has on the generation of private sector investment as a way of reversing the dismal performance of the Nigerian electricity supply industry. In other words private sector investment is critical to the development of the generation capacity of the Nigerian electricity supply industry. Thus power project finance significantly impacts on the flow of private sector investment to the Nigerian electricity supply industry. The finding therefore confirms the views of Babber and Schuster (1998) who argue that private power finance holds a lot of potentials for developing countries power sector. Private power financing according to Babber and Schuster (1998) has brought about significant contribution to the power sectors of developing countries by providing a significant share of the countries investment needs and by bringing new investors and efficiency to the markets with many of the projects structured on BOO and long term PPA(Babber and Schuster, 1998). The findings also corroborate Izaguirre (2004) who reports the significant improvement in the flow of private investment to developing countries power sector reporting that in 2003 alone about 14billion dollars investment flowed to the power sector of the developing countries with IPP projects accounting for about $85 \%$ of the total. This therefore confirms the property rights theories and the bureaucracy theories which argue for private sector participation in infrastructure business as the basis of enhancing operational and allocative efficiency in the infrastructure sector (Alchian, 1965; Niskanen, 1968). It is also consistent with the Averch-Johnson model which argues about the existence of regulatory bias in publically owned and run utilities which operate inefficiently as they do not 
equate their marginal rate of factor substitution to the ratio of their factor cost. The firms are therefore inefficient and crowd out the efficient firms that may enter into the industry (Averch and Johnson, 1962). Thus the need for liberalization and private sector participation. The inefficient performance of developing countries power sector is also attributed to prevalence of political interference as discussed in the influence theories. Private sector financing of electricity infrastructure is therefore the remedy towards reducing political interference and influence which is expected to lead to enhanced efficiency (Milgrom and Roberts, 1990). The findings also tally with OECD/IEA (2007) for privately led power market to deliver the expected benefits competition must flourish across all levels of the markets.

However according to Heron, (1985), many developing countries have difficulty attracting foreign private finance for power projects and have difficulty in mobilizing domestic private finance for reasons specific to the sector and the fact that political pressure keeps tariff below cost recovery level and additionally because domestic savings is generally low and financial market not fully developed. However the findings contrast with (IFC, 1999) who caution against the use of project finance due to the way the 1997 East Asian crisis affected private financed projects in the East Asian countries and the resultant deterioration in the markets for project finance in many developing countries. The findings are also not in line with the work of Bayliss and Hall, (2000) who argue that private power projects are not a solution to power supply constraints in developing countries because of the experience of Philippines and the Dominican Republic where PPA payment commitments in foreign currencies crippled the SOE utilities in these countries.

The implication of these findings is that private power projects have significant potentials for the development of the Nigerian electricity supply industry and the opening up of the industry for private investment provides the opportunity for meeting the investment needs of the industry. However many challenges remain on the road towards private sector investment flow to the Nigerian electricity supply industry due to the undeveloped capital market in the country, investors lack of access to financial resources from both the local and international sources, investors fear of the risks and uncertainties in the Nigerian electricity supply industry, lack of credible off -taker and robust PPA market among others. Thus though there is the strong possibility of the private sector meeting the Nigerian electricity generation needs trough private power project finance, the right environment has to be created for the private sector to have confidence to invest in the Nigerian electricity supply industry.

\section{Recommendations.}

The following recommendations are deemed pertinent.

1. Establishment of macroeconomic stability as a way reducing uncertainties in the economy.

2. Encouragement of Local Entrepreneurs in order to reduce projects' exposure to instability and shock from the global economy.

3. Development of the Financial Services Sector to give opportunities to enhance opportunities for investors to raise funds from the financial services industry.

4. Creation of Industry Friendly Policies in order to reduce the challenges in the industry.

5. Implementation of Governments Policy Incentives in order to make the industry attractive to private investors.

\section{References}

[1]. Adenikinju, A. (2005) Analysis of the Cost of Infrastructure Failure in a Developing Economy; the Case of Electricity Sector in Nigeria. AERC Research Paper 148, Nairobi.

[2]. Ahmed, M. (2010). An Overview of Infrastructure Finance in Nigeria: Current Situation, Challenges, and Way Forward. A paper presented at the CBN Infrastructure Finance Conference held at the Sheraton Hotel and Towers Abuja) 6th to 7th December

[3]. Ajayi, G.A. 1995. Cost-Benefit Analysis of Captive Power Generation by ManufacturingIndustries in Nigeria. Unpublished PhD thesis, Department of Economics, University of Ibadan, Ibadan as cited in Adenikinju, A.(2005) Analysis of the Cost of Infrastructure Failure in a Developing Economy; the Case of Electricity Sector in Nigeria. AERC Research Paper 148, Nairobi

[4]. Arrow, K. and M. Kurz (1970): Public investment, the rate of return and optimal fiscal policy. Johns Hopkins as cited in Calderon $\mathrm{C}$ and Servan L (2008) Infrastructure and Economic Development. World Bank Policy Working Paper no 4712.

[5]. Aschauer, D.A. (1989)“Is Public Expenditure Productive?”Journal of Monetary Economics, 23, 177-200, as cited in Straub S (2008) Infrastructure and Growth in Developing Countries. A Critical Appraisal of Macro Literature. World Bank Policy Research Working Paper no 4590

[6]. Babber, S and Schuster, J. (1998) Power Project Finance: Experience in Developing Countries. RMC Discussions Paper Series no. 119.

[7]. Borg, W. R., Gall, M. D. (1979) Educational Research; An Introduction 3rd ed. Longman Books Inc. New York.

[8]. Calderon, C. and Serven, L. (2008) Infrastructure and Economic Development in the Sub- Saharan Africa. World Bank Policy Research Working Paper no 4712, available @ http;// econworldbank.org.

[9]. Cameron,G. (1996) Infrastructure in the 21 st Century Economy; Overview of Summary and Findings. IWR report 96-FIS 23.

[10]. Coakes, S. J. (2005) SPSSv12 for Windows: Analysis without Anguish. John Wiley and Sons Ltd, Sydney, Australia.

[11]. Cooper, R.D. and Schindler P.S. (2011) Business Research Methods. McGraw-Hill Irwin 7th Edition.

[12]. Dailami, M and M Klien, (1997) Government Support to Infrastructure Projects in Emerging Markets; Averting a New Styled Debt Crisis. A paper presented at the Conference on Managing Government Exposure to Private Infrastructure Projects, Cartegena Columbia 29th -30th May 1997. 
[13]. Dailami, M, Lipkovich, I and Van Dyck, J (1999) INFRISK: a Computer Simulation Approach to Risk Management in Infrastructure Project Finance Transactions. Regulatory Reform and Private Enterprise Division, Economic Development Institute, the World Bank.

[14]. de Leeuw, E., and de Heer, W. (2002), "Trends in Household Survey Non response: A Longitudinal and International Comparison," in Survey Non response, eds. R. M. Groves, D. A. Dillman, J. L. Eltinge, and R. J. A. Little, New York: John Wiley \& Sons.

[15]. Eboh, M.(2012) 'Manitoba : Contract Cancellation Harmful to Nigeria' - Experts . Vanguard Online, 20 th Nov.2012.

[16]. Emeka, E. E. (2010) Causality Analysis of Nigerian Electricity Consumption and EconomicGrowth. Journal of Economics and Engineering, No 4, (pp80-85).

[17]. Escobal, J. and Ponce, C. (2000) “The Benefits of Rural Roads: Enhancing Income Opportunities for the Rural Poor."Group of Analysis for Development (GRADE) working paper No. 40, November as cited in Calderon C and Servan L (2008) Infrastructure and Economic Development. World Bank Policy Research Working Paper no.4712.

[18]. Estache, A., Foster, V. and Wodon, Q. (2002.) "Accounting for Poverty in Infrastructure Reform: Learning from Latin America's Experience." WBI Development Studies, Washington, DC: The World Bank as cited in Calderon C and Servan L (2008) Infrastructure and Economic Development. World Bank Policy Working Paper no4712.

[19]. Estache, A, Goicoechea, A (2005). How wide Spread were Private Investment and Regulatory Reform in Infrastructure Utilities during the 1990s?

[20]. Estache, A, Perelman, S, and Trujillo, L(2005)Infrastructure Performance and Reform in Developing Countries; Evidence from a Survey of Productivity Measures.World Bank Policy Research Working Papers no 3514, available at http;//econ.worldbank.org.

[21]. Fenton, K. A., Johnson,A.M. ,MacManus, S. and Erens, B.(2001:84) Measuring Sexual Behaviour:Methodological Challenges in Survey Research. Journal of Sex Transmission Information vol. 77, pp84-92

[22]. FGN, (2008) Investment Opportunities in the Nigerian Power Sector and Investors' Comforts Guide. A publication of the Federal Ministry of Power, Abuja 2008.

[23]. FGN,(2010) Roadmap to Power Sector Reform. Presidential Speech at the Unveiling of the Government Power Sector Reform held at the Eko Hotel and Suites Lagos August 2010

[24]. Frankfort-Nachmias, C. and Nachmias, D.(1996) Research Methods in the Social Sciences. Hodder Education United Kingdom.

[25]. Gordon, K. (2008) Investment Guarantees and Political Risk Insurance:Institutional Incentives and Development OECD Investment Policy Perspectives available@www.oecd.org/finance/insurance/ 44230805.pdf.

[26]. Hair, J., Anderson, R., Tatham, R., \& Black, W. (2006). Multivariate Data Analysis (4th ed.). Upper Saddle River, NJ: Prentice Hall

[27]. Hinton, P.R., Brownlow, C, Mcmurray, I, and Cozens, B (2004) SPSS Explained. Routledge Inc.,New York.

[28]. Hirschman, A. (1958:83) The Strategy of Economic Development. Yale, New Haven CT as cited in Oyeranti, O. A. (2001) The State of Infrastructure in Ibadan Zone. Proceedings of the 11th CBN Annual Conference.

[29]. IFC (1999) Project Finance in Developing Countries. IFCs Lessons and Experience. No 7.

a. Washington DC.

[30]. Ilori, B.(2002) the Role of Government in Infrastructure Development. Proceedings of the 11th annual Conference of the CBN Research unit.

[31]. Israel, G.D.(1992)Sampling the Evidence of Extension Programme Impact. Institute of Food and Agric. Services, Dept of Agriculture USA.

[32]. Iwayemi, A. (2008a), Investment in Electricity Generation and Transmission in Nigeria; Issues and Options. The Energy Journal 1st Quarterly pp38.

[33]. Iwayemi, A. (2008b) Nigeria Dual Energy Problems; Policy Issues and Challenges. InternationalAssociation of Energy Economists

[34]. Jamasb, T, Mota R, Newbery D and Pollitt, M (2005) Electricity Sector Reform in Developing Countries: A Survey of Empirical Evidence on Determinants and Performance. World Bank Policy Research Working Paper 3549.

[35]. James S (2009) Incentives and Investment: Evidence and Policy Implications. Investment Climate Advisory Services, the World Bank Group..

[36]. Khandker, S, V. Levy, D. Filmer (1994) Schooling and Cognitive Achievement of Children in Morocco. Discussion Paper No 264 World Bank as cited in Agenor, P.R. and B Moreno-Dodson (2006) Public Infrastructure and growth; New Channels and Policy Implication. World Bank Working Paper 4064, November 2006.

[37]. Kerekezi, S,Kimani, J, Wangeci, J (2001) Power Sector Reform in Africa. Proceedings of a Regional Policy Seminar 24th to 25th April 2001, Nairobi Kenya.

[38]. Lee, K S, Anas A, and Gi-Taik O.(1999)“Costs of Infrastructure Deficiencies for manufacturing in Nigerian, Indonesian, and Thai Cities," Urban Studies, 36 (December 1999), 2135-49.

[39]. Lokshin, M. and Ruslan Y. (2005)“Has rural infrastructure rehabilitation in Georgia helped the poor?”The World Bank Economic Review 19(2), 311-333 as cited in Calderon C and Servan L(2008)Infrastructure and Economic Development. World Bank Policy Research Working Paper 4712

[40]. Mu, R and Dominique van de Walle (2007)“Rural Roads and Poor Area Development in Vietnam.” World Bank Policy Research Working Paper 4340, August as cited in Calderon C and Servan L(2008) Infrastructure and Economic Development. World Bank Policy Research Working Paper 4712.

[41]. Obadote, D J ; (2009) Energy Crisis in Nigeria; Technical Issues and Solutions; Power Sector Prayer Conference June 25th -27th 2009

[42]. OECD(2007) Infrastructure to 2030: Mapping Policy for Electricity ,Water and Transport. Vol. 2. Organization of EconomicCooperation and Development.

[43]. Okoro, O. I. and Chikunu, E. (2007) Power Sector Reform in Nigeria; Opportunities and Challenges. Journal of Energy in Southern Africa Vol. 18, N03 pp52-57.

[44]. Oppenheim, A.N.(1996).Questionnaire Design, Interviewing and Attitude Measurement.

a. Pinta Publishers, London.

[45]. Osborne, J.S. and Waters E. (2002) Four Assumptions of Multiple Regression that Researchers should Know. Practical Assessment, Research and Evaluation 8 (2). Available@ http://ericae.net/pare/getvn.asp?v=8\&n=2.

[46]. Oyeranti, O.A. (2001:13) The State of Infrastructure in Ibadan Zone. Proceedings of the 11thAnnual Conference of the Research Unit CBN.

[47]. Merna, T and C Njiru(1998) Financing and Managing Infrastructure Projects. Asia Law Review, Hongkong

[48]. Merna, T and C Njiru, (2002) Financing Infrastructure Projects. Thomas Telford London 
[49]. Morisset, J. and Pirnia, N. 2001, "How Tax Policy and Incentives Affect Foreign Direct Investment: A Review, in Wells and others, eds., Using Tax Incentives to Compete for Foreign Investment, World Bank as cited in James S(2009) Incentives and Investment: Evidence and Policy Implications. Investment Climate Advisory Services, the World Bank.

[50]. Nnaji, B. (2008) IPPs Obstacle to Boosting Power Supply. Quarterly Meeting of the Nigerian Electricity Regulatory Commission and IPPs. Nov 2008

[51]. Nnaji, B (2009) Ministerial Press Briefing by the Hon Minister Federal Ministry of Energy. Reported in Daily Trust News Papers Ltd 6th November 2009.

[52]. Nnaji, B (2011) Power Sector Reform Outlook in Nigeria; Challenges, Constraints and Opportunities. National Association of Energy Economists 4th Annual Conference, Abuja, April 2011.

[53]. NERC, (2008) Tariff Regulation in the Nigerian Electricity Supply Industry. A Presentation by Market Competition and Rates Division, NERC at the NERC/NARUC Workshop July 2008.

[54]. Pallant, J (2001) SPSS Survival Manual. Open University Press ,Philadelphia.

[55]. Pallant, J (2011) SPSS Survival Manual. Open University Press ,Philadelphia.

[56]. Reinikka, R. and J. Svensson, (1999) 'How Inadequate Provision of Public Infrastructure and Services Affects Private Investment', The World Bank, Policy Research Working Paper Series: 2262.

[57]. Reinikka, R and J Svenson, (2002) Coping with Poor Public Capital. Journal of Economic Development .No 69, p5 -69 as cited in Agenor, P.R. and Moreno-Dodson, (2006) Public Infrastructure and Growth; New Channels and Policy Implications. World Bank Policy Research Working Paper no 4064.

[58]. Schneider V. and Jager A. (2003) The Privatization of Infrastructure in the Theory of theState: an Empirical Overview of Discussion of Competing Theoretical Explanations in Wubben E. F. M. and Hulsink W(ed) On Creating Competition and Strategic Restructuring: Regulatory Reform in Public Utilities. ERIM Report Series in Management ERS 2003-051 RG available @ www.erim.eur.nl.

[59]. Tabachnick G.B. and Fidell L. S. (2007) Multivariate Data Analysis. Pearson International Edition. New York.

[60]. Thurstone L. L. and Kenny K.K. (1946) A Comparsion of the Thurstone and Likert Technique of Attitude Scale Construction. Journal of Applied Psychology. Vol $30,1946$.

[61]. Todaro, M P and C Smith (2006) Economic Development. McMillan publishers London.

[62]. UNCITRAL, (2001) Legislative Guide on Privately Financed Infrastructure Projects .United Nations Commission on International Trade Law, United Nations, New York.

[63]. Veal, A. J. (2005) Business Research Methods; a Managerial Approach. PearsonEducation Australia.

[64]. Vernon, R (1971) Sovereignty at Bay: The Multinational Spread of US Enterprises as cited in Woodhouse J. E. Obsolescing Bargain Redux? Foreign Investment in the Electric Power of Developing Countries. Journal of International Law and Politics. Vol. $38: 121$.

[65]. Victor, D.G., Heller T.C, House J, and Woo P.Y. (2004) The Experience with Independent Power Projects in Developing Countries. Introduction and Case Study Methods. P.E.S.D. Working Paper no23.

[66]. Yamane, T. (1967). Statistics, an Introductory Analysis, 2nd Ed., New York: Harper and Row as cited by Israel G.D. (1992) Sampling the Evidence of Extension Programme Impact. Institute of Food and Agric. Services, Dept of Agriculture USA.

[67]. Wallsten, S ; Clarke, G ; Haggarty, L; Kaneshiro, M; Noll, R; Shirley ,M and Xu LC(2004) New Tools for Studying Network Industry Reforms in Developing Countries: The Telecommunications and Electricity Data Base. Review of Network Economics, Vol.3, Issue 3.

[68]. Woodhouse,E.J.(2005).A Political Economy of International Infrastructure Contracting: Lessons from the Independent Power Producers Experience. PESD Working Paper No.52 Stanford University. Available @ http://pesd.stanford.edu

[69]. Woodhouse, E.J. (2006) Obsolescing Bargain Redux? Foreign Investment in the Electric Power Sector in Developing Countries. International Law and Politics Vol.38:121.

[70]. Zhang, Y.F., Parker D. and Kirkpatrick C.,(2002) Electricity Sector Reform in Developing Countries:An Econometric Assessment of the Effects of Privatization. Competition and Regulation. Aston Business School Research Papers Series no, RPO216. 